\title{
PENGEMBANGAN MODEL MEDIA VIDEO PADA PEMBELAJARAN PRAKTIK PEMESINAN BUBUT
}

\author{
Ridwan Oktavian Hananta ${ }^{1}$, Thomas Sukardi ${ }^{2}$ \\ 1,2Jurusan Pendidikan Teknik Mesin FT UNY \\ Email:ridwan_oktavian@ymail.com
}

\begin{abstract}
This study aims to examine the development and the usability of a video-based learning media on the subject of lathe metric threading. The study was carried out in class XI of Machining program study. This research is a Research and Development using ADDIE (Analysis-Design-Development-ImplementEvaluation) learning design. Data collection techniques that was used were questionnaires and research documentation. The development process of video models is carried out by observation and validation from material experts, media experts and subject teachers. The development of the media resulted in the videobased learning media products in the form of an $\mathrm{mp} 4$ video formats. The evaluation of the video media resulted in an average usability of $78.85 \%$, which lies in the 'very good' category. In conclusion, the videobased learning media can be used in the teaching and learning process.
\end{abstract}

Keywords: addie, video-based learning media, lathe machining

\section{ABSTRAK}

Penelitian ini bertujuan untuk mengetahui pengembangan dan kelayakan media pembelajaran berbasis video pada proses pembuatan ulir metris dengan menggunakan mesin bubut pada kelas XI Teknik Pemesinan. Penelitian ini merupakan Research and Developtment menggunakan desain pembelajaran ADDIE (Analyze-Design-Development-Implement-Evaluate). Teknik pengumpulan data penelitian ini menggunakan angket serta dokumentasi penelitian Proses pengembangan model media video dilakukan dengan cara observasi dan melalui validasi dari ahli materi, ahli media dan guru mata pelajaran. Hasil pengembangan media diperoleh produk media pembelajaran berbasis video berbentuk mp4 pada materi pembuatan ulir metris dengan proses pembubutan. Hasil evaluasi produk media video diperoleh persentase kelayakan rata-rata sebesar $78.85 \%$ yang termasuk dalam kategori sangat baik. Dengan demikian media pembelajaran berbasis video pada pembelajaran praktik pemesinan bubut dinyatakan layak digunakan pada proses pembelajaran.

Kata kunci: ADDIE, media pembelajaran berbasis video, pemesinan bubut, pembubutan ulir metris

\section{PENDAHULUAN}

Pengembangan program media bertujuan untuk menghasilkan media pembelajaran yang memanfaatkan teknologi komunikasi dan informasi dalam rangka meningkatkan mutu pendidikan dan pemerataan pendidikan. Salah satu kegiatan pokok yang dilakukan adalah pengembangan program media radio, audio, televisi, video, multimedia dan internet untuk pembelajaran.

Kegiatan belajar mengajar yang diperoleh dari hasil observasi selama PLT (Praktik Lapangan Terbimbing ) ditemukan bahwa metode pembelajaran yang digunakan masih konvensional, sehingga beberapa siswa merasa bosan terhadap pelajaran dan tidak fokus terhadap materi yang disampaikan oleh guru. Salah seorang guru mata pelajaran Kerja Mesin menyampaikan bahwa siswa kesulitan dalam memahami teori pembubutan ulir metris, sehingga membutuhkan waktu yang lama untuk menyampaikan materi dan sangat diperlukan adanya media pembelajaran. Dilihat dari kegiatan belajar, dibutuhkan media pembelajaran untuk menarik perhatian siswa agar lebih fokus saat proses pembelajaran.

Kegiatan belajar mengajar lainnya yang diperoleh dari hasil observasi selama PLT setiap kelas telah dilengkapi LCD Proyektor, dengan demikian proses kegiatan belajar di 
kelas sebagian guru telah menggunakan Microsoft Power Point. Maka dari itu, penerapan media pembelajaran berbasis video bertujuan untuk mengoptimalisasi fasilitas yang telah ada di setiap kelas. Teori pada mata pelajaran kerja mesin dasar sangat cocok dengan media ini karena dapat menayangkan mesin dan proses pemesinan secara nyata, sehingga dengan adanya penerapan media pembelajaran yang berbasis video ini akan lebih menarik perhatian siswa yang pasif menjadi aktif dan dari yang tidak tahu akan menjadi ingin tahu tentang proses yang terjadi, khususnya dalam praktik mesin seperti mesin bubut dalam membuatan ulit metris.

Kata media berasal dari Bahasa Latin dan merupakan bentuk jamak dari kata medium yang secara harfiah berarti perantara atau pengantar. Dalam Bahasa Arab, media adalah perantara atau pengantar pesan dari pengirim kepada penerima. Gerlach \& Ely dalam Arsyad (2013: 3) menyatakan bahwa media apabila dipahami secara garis besar adalah manusia, materi, atau kejadian yang membangun kondisi yang membuat siswa mampu memperoleh pengetahuan keterampilan, atau sikap. Dalam pengertian ini, guru, buku teks, dan lingkungan sekolah merupakan media. Secara khusus, pengertian media dalam proses belajar mengajar cenderung diartikan sebagai alat-alat grafis, photografis, atau elektronis untuk menangkap, memproses dan menyusun kembali informasi visual atau verbal.

Media adalah suatu perantara antara pihak pengantar dengan penerima atau dalam konteks ini adalah guru dengan murid, baik berupa sebuah alat cetak maupun audio visual. Manfaat praktis dari penggunaan media pembelajaran di dalam proses belajar mengajar sebagai berikut : (1) Media pembelajaran dapat memperjelas penyajian pesan dan infromasi sehingga dapat memperlancar dan meningkatkan proses dan hasil belajar, (2) Media pembelajaran dapat meningkatkan dan mengarahkan perhatian anak sehingga dapat menimbulkan motivasi belajar, interaksi yang lebih langsung antara siswa dan lingkungannya dan kemungkinan siswa untuk belajar secara mandiri sesuai dengan kemampuan dan minatnya (3) Media pembelajaran dapat mengatasi keterbatasan indera, ruang dan waktu (4) Media pembelajaran dapat memberikan kesamaan pengalaman kepada siswa tentang peristiwa - peristiwa dilingkungan mereka serta memungkinkan terjadinya interaksi langsung dengan guru, masyarakat dan lingkungannya misalnya melalui karyawisata, kunjungan kunjungan ke museum atau kebun binatang

Media pembelajaran berbasis video dapat digolongkan ke dalam jenis media Audio Visual Aids (AVA) atau media yang dapat dilihat atau didengar oleh indra manusia. Media ini merupakan media yang memberikan informasi lebih lengkap dari media yang lain karena banyak merangsang indra manusia.

Proses pembelajaran akan lebih efektif apabila pembelajaran menggunakan media pembelajaran berbasis video seperti yang telah didefinisikan oleh para ahli. Ada beberapa kelebihan video ketika digunakan sebagai media pembelajaran, diantaranya menurut Nugent dalam Smaldino (2008: 310) yang menyatakan bahwa video merupakan media yang cocok untuk berbagai ilmu pembelajaran, seperti kelas, kelompok kecil, bahkan satu siswa seorang diri sekalipun. Hal itu tidak dapat dilepaskan dari kondisi para siswa saat ini yang tumbuh berkembang dalam dekapan budaya televisi, di mana paling tidak setiap 30 menit menayangkan program yang berbeda. Oleh sebab itu, video dengan durasi yang hanya beberapa menit mampu memberikan pemahaman lebih bagi guru dan dapat mengarahkan pembelajaran secara langsung pada kebutuhan siswa.

Cepi Riyana (2007: 17-18) menjelaskan bahwa secara garis besar terdapat tiga kegiatan utama dalam memproduksi pengembangan program video yaitu tahap pra-produksi, produksi, dan pasca produksi yang dijelaskan melalui bagan Gambar 1. 


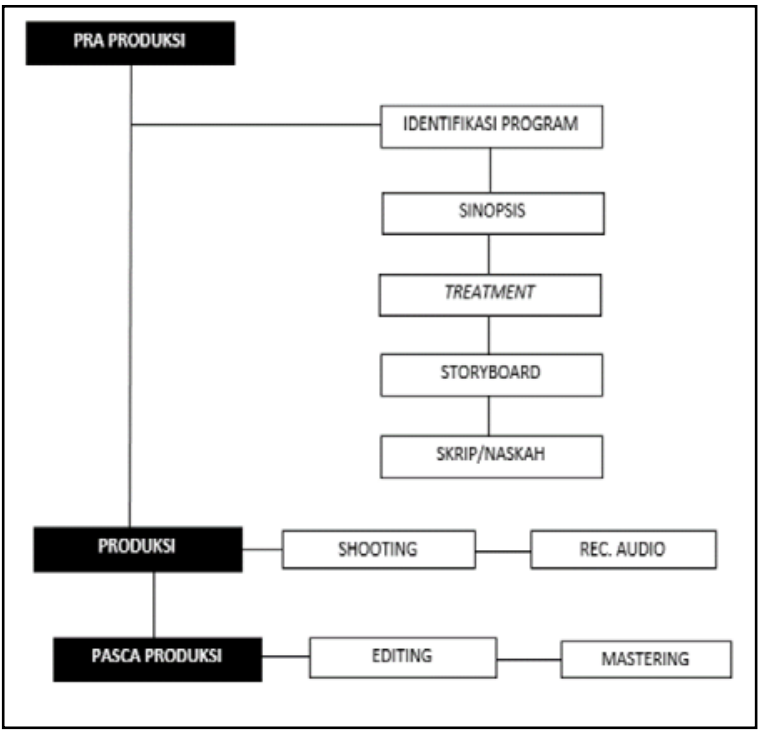

Gambar1. Tahap Kegiatan Produksi Video

Guru mata pelajaran Kerja Mesin masih kurang kreatif dalam menyampaikan materi pembelajaran yang mengakibatkan siswa kelas XI Mesin kurang memperhatikan dan memahami bahan ajar. Hal ini juga berdampak pada kegiatan praktikum siswa yang masih mengalami kebingungan mengenai tahap-tahap pembuatan produk. Oleh karena itu, peneliti mengembangkan media pembelajaran untuk membantu proses pembelajaran siswa baik dalam teori maupun praktikum.

Penelitian yang dilakukan Wawan Sabtono (2015) tentang Pengaruh Penggunaan Video Pembelajaran Terhadap Prestasi Praktik Pemesinan di SMK Muhammadiyah Prambanan bahwa pengaruh penggunaan media video pembelajaran praktik dapat diketahui dengan adanya peningkatan rata-rata prestasi belajar praktik. Rata-rata prestasi belajar praktik siswa kelas kontrol didapat 85,22\% dan kelas eksperimen didapat $88,66 \%$. Hal tersebut menunjukan peningkatan prestasi belajar praktik siswa antara kelas kontrol dan kelas eksperimen sebanyak 3,44\%.

Penelitian yang dilakukan Fajar Uut Purnomo (2017) tentang Pengembangan Video Tutorial Untuk Pembelajaran Gambar Manufaktur SMK Kelas XI bahwa Hasil penelitian ini menunjukan bahwa media pembelajaran yang dibuat sangat layak digunakan dalam proses pembelajaran bagi siswa kelas XI di SMK N 1 Kota Magelang. Hal tersebut berdasarkan penilaian yang telah dilakukan pada ahli materi dengan rerata 3,53 (88,13\%) diklasifikasikan sangat baik, rerata skor ahli media 3,35 (83,88\%) diklasifikasikan sangat baik, rerata skor uji coba terbatas 3,29 (82,19\%) diklasifikasikan sangat baik.

Penelitian yang dilakukan Imam Mustholiq MS, Sukir dan Ariadie Chandra N (2007) tentang Pengembangan Media Pembelajaran Interaktif Berbasis Multimedia Pada Mata Kuliah Dasar Listrik bahwa hasil pengembangan media pembelajaran interakti berbasis multimedia mata kuliah Dasar Listrik mempunyai unjuk kerja yang baik, yang ditunjukan skor rata-rata penilaian diberikan oleh ahli media, ahli materi dan mahasiswa terhadap unjuk kerja hasil pengembangan media pembelajaran interaktif tersebut adalah 3.18 atau secara persentase sebesar $79.71 \%$.

Uraian diatas menunjukan bahwa media pembelajaran berbasis audio visual layak untuk diterapkan pada proses pembelajaran serta dapat menunjang kreatifitas peserta didik.

\section{METODE}

Pengembangan model pembelajaran yang digunakan dalam penelitian ini adalah Model Desain Pembelajaran ADDIE (Analysis-DesignDevelop-Implement-Evaluate). Selain itu juga dipadukan menurut langkah-langkah penelitian pengembangan yang direkomendasikan oleh Borg dan Gall. Dasar pertimbangannya adalah bahwa model tersebut cocok untuk mengembangkan produk model instruksional/ pembelajaran yang tepat sasaran, efektif dan dinamis dan sangat membantu dalam pengembangan pembelajaran bagi guru.

Penelitian dan pengembangan media pembelajaran berbasis video pada mata pelajaran Kerja Mesin untuk pembuatan ulir metris dilaksanakan di SMK PIRI Sleman pada bulan Mei 2018. Subjek penelitian dari penelitian ini adalah siswa kelas XI jurusan Teknik sebanyak 23 siswa. Sedangkan objek 
penelitian adalah media pembelajaran berbasis video dalam pembelajaran Kerja Mesin untuk pembuatan ulir metris.

Prosedur penelitian pengembangan yang digunakan adalah model desain instruksional ADDIE yang dikembangkan oleh Reiser dan Mollenda (1990). Gambar 2 merupakan langkah yang digunakan pada model ADDIE.

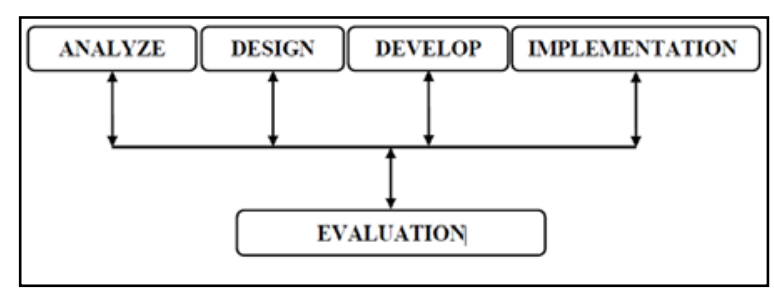

Gambar 2. Langkah Umum Desain Pembelajaran ADDIE

Tahap pertama dalam penelitian ini adalah menganalisis situasi proses pembelajaran dari lingkungan sekolah. Dalam mendapatkan hasil analisis, peneliti melakukan observasi di sekolah. Dari hasil observasi pada proses belajar mengajar (PBM) berlangsung didapat beberapa aspek yang mendukung peneliti untuk membuat media pembelajaran berbasis video, antara lain (1) Media Pembelajaran, (2) Metode Pembelajaran, (3) Materi, (4) Problematika selama PBM.

Tahap kedua melihat hasil analisa untuk menunjang keaktifan siswa dalam kegiatan belajar, maka peneliti mendesain media pembelajaran berbasis video. Dengan langkah pembuatan sebagai berikut, (1) Membuat storyboard, Garis Besar Program Media (GBPM) (2) Membuat naskah dalam pengembangan media pembelajaran berbasis video ini merupakan penjelasan yang akan dibuat dalam bentuk audio. Penulisan naskah dibuat peneliti dengan memperhatikan aspek materi yang disampaikan. Aspek yang terdapat dalam video pembelajaran antara lain : a) Tujuan pembelajaran, b) Pengertian ulir, c) Bagian-bagian ulir, d) Fungsi ulir, dan e) Proses pembuatan ulir metris; (3) Membentuk tim produksi pada pengembangan media video ini berisi pengambilan gambar (shooting video) dan rekaman suara (recording audio) sesuai dengan isi naskah yang telah dibuat sebelumnya.

Tahap ketiga hasil observasi yang dilakukan peneliti didapati bahwa guru mata pelajaran masih menggunakan media konvensional dan sesekali menggunakan media Microsoft Powerpoint, maka peneliti mengembangkan media pembelajaran menjadi media pembelajaran berbasis video. Model media pembelajaran berbasis video ini dikembangkan sesuai dengan permasalahan dan kebutuhan yang terdapat pada proses pembelajaran kelas XI Teknik Pemesinan. Model media pembelajaran berbasis video akan menjelaskan materi mengenai proses pembuatan ulir metris.

Tahap keempat media pembelajaran ini menampilkan visualisasi proses praktik pembuatan ulir metris sesuai dengan materi yang disampaikan dan model media video ini menerapkan silabus yang digunaan di sekolah serta menggunakan kurikulum 2013 dengan kompetensi dasar 3.1 dan 4.1.

Tahap kelima pada evaluasi didapat beberapa revisi dari ahli materi, ahli media dan guru mata pelajaran. Beberapa aspek yang perlu dibenahi supaya model media video ini dapat digunakan tanpa adanya perbaikan lagi. Metode pengumpulan data pada saat penerapan media pembelajaran berbasis video di kelas XI Teknik Pemesinan peneliti menggunakan metode angket dan dokumentasi. Angket digunakan untuk mengumpulkan informasi sebagai bahan dasar dalam mengetahui penilaian terhadap media pembelajaran pada uji validasi dan kelayakan. Instrumen yang dilakukan oleh ahli media, ahli materi dan user sesuai dengan kriteria dalam mereview perangkat lunak media pembelajaran berdasarkan kualitas.

Teknik pengumpulan data dengan metode dokumentasi untuk mengetahui kondisi subjek sebelum dan sesudah diterapkan media pembelajaran berbasis video dalam mata pelajaran Kerja Mesin 
Teknik analisis data yang digunakan dalam penelitian ini yaitu menggunakan skala Likert. Menurut Sugiyono (2011: 107) skala Likert digunakan untuk mengukur sikap, pendapat dan presepsi seseorang atau kelompok tentang fenomena sosial. Kriteria penilaian jawaban setiap item instrumen dengan skala Likert mempunyai gradasi dari sangat positif sampai sangat negatif, dimana memiliki bobot penilaian antara 1-4 dan alternatif jawaban berupa Kurang Baik, Cukup Baik, Baik dan Sangat Baik pada instrumen validasi ahli materi, validasi ahli media, dan validasi untuk guru. Sedangkan pada instrumen penilaian/respon siswa menggunakan skala pengukuran likert scale dengan pilihan jawaban 1-4 dengan penilaian Sangat Tidak Setuju, Tidak Setuju, Setuju, dan Sangat Setuju.

Tabel 1. Kriteria Penilaian Skala Likert

\begin{tabular}{ccc}
\hline \multicolumn{2}{c}{ Alternatif Jawaban } & Skor \\
\hline Sangat Baik & Sengat Setuju & 4 \\
Baik & Setuju & 3 \\
Tidak Baik & Tidak Setuju & 2 \\
Sangat Tidak & Sangat Tidak Setuju & 1 \\
Baik & & \\
\hline
\end{tabular}

Suharsimi Arikunto (1993: 207) menjelaskan bahwa data diskriptif kuantitatif adalah data yang berwujud angka-angka hasil perhitungan atau pengukuran dapat diproses dengan cara dijumlah, dibandingkan dengan jumlah yang diharapkan dan diperoleh persentase. Pencarian persentase dimaksudkan untuk mengetahui status sesuatu yang dipersentasekan dan disajikan tetap berupa persentase.

Tabel 2. Tabel Skala Persentase

\begin{tabular}{ccc}
\hline Persentase & Skala Nilai & Interpetasi \\
\hline $76-100 \%$ & 4 & Sangat Layak \\
$56-75 \%$ & 3 & Layak \\
$40-55 \%$ & 2 & Cukup Layak \\
$0-25 \%$ & 1 & Kurang Layak \\
\hline
\end{tabular}

Tabel skala persentase di atas digunakan untuk menentukan nilai kelayakan produk yang dihasilkan. Nilai kelayakan untuk produk pengembangan media pembelajaran berbasis video dalam pembelajaran Kerja Mesin dalam pembuatan ulir metris ditetapkan kriteria kelayakan minimal layak.

\section{HASIL DAN PEMBAHASAN}

Bentuk produk media pembelajaran pada mata pelajaran kerja mesin dengan pokok bahasan pembubutan ulir metris adalah media pembelajaran berbasis video. Produk media ini menyuguhkan lima materi yaitu : tujuan pembelajaran, pengertian ulir, fungsi ulir, bagian - bagian ulir dan proses pembuatan ulir metris. Media ini sangat praktis karena berbentuk file mp4 sehingga media ini dapat langsung digunakan dengan komputer atau laptop.

File media pembelajaran yang dikembangkan sebesar 291 MB dan sangat mudah dijalankan meski menggunakan komputer atau laptop dengan spesifikasi rendah. Selain itu media pembelajaran ini juga sangat mudah digunakan, karena tidak perlu keahlian khusus untuk mengaplikasikannya. Dalam pengoperasiannya, seperti memutar atau menjalankan video pada umumnya dan menggunakan navigasi pause yang terdapat dalam software pemutar video untuk menghentikan video sementara.

Struktur media pembelajaran berbasis video ini memuat halaman menu utama yang berisi pokok bahasan yang akan dipelajari dalam media pembelajaran ini. Poko bahasan yang terdapat dalam media ini yaitu, tujuan pembelajaran, pengertian ulir, bagian - bagian ulir, fungsi ulir dan proses pembuatan ulir metris. Dalam tujuan pembelajaran, pengertian ulir dan fungsi ulir berisi tulisan - tulisan dengan warna background yang menarik. Pada pokok bahasan bagian - bagian ulir dilengkapi gambar. Proses pembuatan ulir metris terdiri dari langkah - langkah dalam pembuatan ulir metris. Proses pembuatan ulir metris berisikan video nyata pembuatan ulir metris. Media ini juga dilengkapi dengan narator sebagai penjelas penyampaian materi dan backsong supaya 
siswa tidak jenuh dalam mempelajari materi yang disampaikan. Pada bagian terakhir media ini terdapat informasi tentang media yang dikembangkan dan beberapa nama yang ikut berperan dalam pembuatan media

Penggunaan media pembelajaran berbasis video sangat mudah, karena tidak memerlukan software khusus. Untuk orang awam yang belum terampil menggunakan komputer atau laptop juga tidak membutuhkan waktu yang lama untuk mempelajarinya. Ketika media sudah dijalankan, materi yang terdapat pada media akan terus berjalan seperti pemutaran video pada umumnya. Apabila ada materi yang penting untuk dipelajari dan akan menghentikan video, operator cukup memilih tombol pause yang terdapat pada software pemutar video atau menekan "spasi" pada keyboard. Setelah media selesai digunakan, operator cukup menekan tanda silang yang terdapat pada pojok kanan atas layer komputer/ laptop.

Kelayakan media pemelajaran berbasis video pada mata pelajaran kerja mesin divalidasi oleh ahli materi dan ahli media, serta guru Mata Pelajaran untuk dinilai kelayakan dari beberapa aspek kelayakan media pembelajaran pada mata pelajaran kerja mesin. hasil revisi berdasarkan saran dan masukan dari ahli mteri, ahli media dan guru diujicobakan pada siswa kelas XI jurusan Teknik Pemesinan yang berjumlah 23 siswa untuk mendapat tanggapan/respon terhadap media yang dikebangkan. Hasil dari penilaian siswa dijadikan acuan sebagai persetujuan siswa bahwa media pembelajaran yang dikembangkan dapat digunakan sebagai media pembelajaran yang layak.

Hasil persentase kelayakan yang diperoleh dari ahli materi untuk aspek pendahuluan adalah sebesar $66.67 \%$ termasuk pada klasifikasi baik dan untuk aspek isi materi adalah sebesar $70 \%$ termasuk pada klasifikasi baik. Hasil selengkapnya dapat dilihat pada Tabel 3.

Berdasarkan data hasil validasi dari ahli materi diatas, diambil kesimpulan bahwa tingkat kelayakan media pembelajaran mendapat persentase sebesar $68.34 \%$ dan termasuk pada klasifikasi baik, dan disimpulkan bahwa media pembelajaran dinyatakan layak atau dapat digunakan dengan revisi seperlunya dan diujicobakan ke siswa.

Tabel 3. Penilaian Validasi Ahli Materi

\begin{tabular}{cccc}
\hline \multicolumn{4}{c}{ Validasi Ahli Materi } \\
\hline No & Aspek & Persentase & Klasifikasi \\
\hline 1 & Pendahuluan & 66.67 & Baik \\
2 & Isi Materi & 70 & Baik \\
\hline & Rata-rata & 68.34 & Baik \\
\hline
\end{tabular}

Hasil persentase kelayakan yang diperoleh dari penilaian ahli media untuk aspek visual adalah sebesar 85\% termasuk dalam klasifikasi sangat baik, aspek audio adalah sebesar 95\% termasuk dalam klasifikasi sangat baik, aspek bahasa dan tipografi adalah sebesar 83.3\% termasuk dalam kasifikasi sangat baik, dan aspek pemograman adalah sebesar 75\% termasuk dalam klasifikasi baik. Hasil selengkapnya dapat dilihat pada Tabel 4 .

Tabel 4. Penilaian Validasi Ahli Media

\begin{tabular}{cccc}
\hline \multicolumn{4}{c}{ Validasi Ahli Media } \\
\hline No. & Aspek & Persentase & Klasifikasi \\
\hline 1 & Visual & 85 & Sangat Baik \\
2 & Audio & 95 & Sangat Baik \\
3 & Bahasa dan & 83.3 & Sangat Baik \\
& Tipografi & 75 & Baik \\
4 & Pemograman & 84.6 & Sangat Baik \\
\hline & Rata-rata & &
\end{tabular}

Berdasarkan data hasil validasi dari ahli media diatas, diambil kesimpulan bahwa tingkat kelayakan media pembelajaran mendapat persentase sebesar $84.6 \%$ dan termasuk pada klasifikasi "sangat baik", dan disimpulkan bahwa media pembelajaran dinyatakan layak atau dapat digunakan dengan revisi seperlunya dan diujicobakan ke siswa.

Hasil persentase kelayakan yang diperoleh dari penilaian guru Mata Pelajaran mata pelajaran kerja mesin dasar untuk aspek pendahuluan adalah sebesar $100 \%$ termasuk dalam klasifikasi sangat baik, aspek isi materi adalah sebesar $79.5 \%$ termasuk dalam klasifikasi sangat baik, aspek komunikasi 
adalah sebesar $100 \%$ termasuk dalam klasifikasi sangat baik, aspek desain adalah sebesar $97.5 \%$ termasuk dalam klasifikasi sangat baik dan aspek sajian adalah sebesar 75\% termasuk dalam klasifikasi sangat baik. Hasil selengkapnya dapat dilihat pada Tabel 5.

Tabel 5. Penilaian Validasi Guru Mata Pelajaran Validasi Guru Mata Pelajaran

\begin{tabular}{cccc}
\hline No. & Aspek & Persentase & Klasifikasi \\
\hline 1 & Pendahuluan & 100 & Sangat Baik \\
2 & Isi Materi & 79.5 & Sangat Baik \\
3 & Komunikasi & 100 & Sangat Baik \\
4 & Desain & 97.5 & Sangat Baik \\
5 & Format Sajian & 75 & Sangat Baik \\
\hline & Rata-rata & 90.4 & Sangat Baik \\
\hline
\end{tabular}

Berdasarkan data hasil validasi dari guru Mata Pelajaran diatas, diambil kesimpulan bahwa tingkat kelayakan media pembelajaran mendapat persentase sebesar $90.4 \%$ dan termasuk pada klasifikasi baik, dan disimpulkan bahwa media pembelajaran dinyatakan layak atau dapat digunakan dengan revisi seperlunya dan diujicobakan ke siswa.

Selain memberikan penilaian terhadap media yang dikembangkan, validator ahli materi, ahli media dan guru Mata Pelajaran juga memberikan komentar untuk perbaikan media pembelajaran. Komentar tersebut kemudian ditindaklanjuti berupa perbaikan sehingga dapat menjadi penyempurna media pembelajaran agar layak untuk digunakan dalam proses pembelajaran. Adapun komentar dari ahli materi, ahli media dan guru Mata Pelajaran terhadap media pembelajaran pada teori pemesinan bubut adalah sebagai berikut:

Ahli materi memberikan beberapa komentar terhadap media permbelajaran berbasis video, antara lain: a) Untuk pembuatan alur hendaknya disajikan juga parameter pemotongannya yang harus ditentukan, b) Harap diperjelas dalam skripsi bahwa yang disusun dalam media hanya tetang pembubutan ulir metris, c) Diperjelas juga terkait denga kompetensi dasar yang ada dalam silabus, d) Karena Media ini untuk SMK PIRI Sleman, maka job sheet nya jangan menggunakan job Pendidikan Teknik Mesin. Apalagi yang diajarkan dalam video berbeda dengan job sheet yang dilampirkan.

Ahli media memberikan beberapa komentar terhadap media pembelajaran berbasis video, antara lain : a) Perbaikan pada motion gambar yang terlalu cepat, b) Gambar yang tidak jelas di ganti, c) Tulisan pada subtitle diperjelas. Guru Mata Pelajaran memberikan beberapa komentar terhadap media pembelajaran berbasis video adalah urutan dalam proses pengerjaan benda kerja disesuaikan dengan SOP.

Pengambilan data dilakukan diruang kelas dengan cara menayangkan media pembelajaran kepada siswa dengan proyektor, kemudian setelah penayangan media selesai siswa memberikan penilaian pada angket yang diberikan oleh peneliti.

Hasil persentase kelayakan yang diperoleh dari respon siswa untuk aspek komunikasi adalah sebesar $77.54 \%$ termasuk pada klasifikasi sangat setuju, untuk persentase kelayakan aspek desain adalah sebesar $73.5 \%$ termasuk pada klasifikasi setuju dan untuk persentase kelayakan aspek manfaat adalah sebesar $80.1 \%$ termasuk pada klasifikasi sangat setuju. Hasil penilaian respon siswa untuk penilaian seluruh aspek. Data selengkapnya bisa dilihat pada Tabel 6 .

Tabel 6. Tabel Hasil Respon Siswa

\begin{tabular}{cccc}
\hline \multicolumn{4}{c}{ Respon Penilaian Siswa } \\
\hline No. & Aspek & Persentase & Klasifikasi \\
\hline 1 & Komunikasi & 77.54 & Sangat Setuju \\
2 & Desain & 73.5 & Setuju \\
3 & Manfaat & 80.1 & Sangat Setuju \\
\hline & Rata-rata & 77.05 & Sangat Setuju \\
\hline
\end{tabular}

Berdasarkan data hasil respon penilaian siswa di atas, diambil kesimpulan bahwa media yang dikembangkan oleh peneliti memiliki tingkat kelayakan sebesar $77.05 \%$ dan termasuk pada klasifikasi sangat setuju, dan media pembelajaran dinyatakan layak atau dapat digunakan untuk proses pembelajaran.

Persentase pencapaian hasil validasi ahli materi dan ahli media, penilaian guru Mata 
Pelajaran serta hasil respon penilaian siswa terhadapat media pembelajaran berbasis video ini kemudian dijumlahkan untuk menentukan rata-rata penilaian media pembelajaran berbasis video. Data hasil rata-rata penilaian media pembelajaran berbasis video dapat dilihat pada Tabel 7.

Tabel 7. Hasil Rata-rata Penelitian Media Pembelajaran Berbasis Video

\begin{tabular}{cccc}
\hline \multicolumn{4}{c}{ Penilaian Media Pembelajaran } \\
\hline No. & Aspek & Persentase & Klarifikasi \\
\hline 1 & $\begin{array}{c}\text { Validasi Ahli } \\
\text { Materi }\end{array}$ & 63.36 & Baik \\
2 & $\begin{array}{c}\text { Validasi Ahli } \\
\text { Media }\end{array}$ & 84.6 & Sangat Baik \\
3 & $\begin{array}{c}\text { Penilaian Guru } \\
\text { Mata Pelajaran } \\
\text { Respon }\end{array}$ & 90.4 & Sangat Baik \\
4 & $\begin{array}{c}\text { Penilaian Siswa } \\
\text { Rata-rata }\end{array}$ & 77.05 & Sangat Baik \\
\hline & 78.85 & Sangat Baik \\
\hline
\end{tabular}

Hasil persentase kelayakan yang diperoleh dari validasi ahli materi adalah sebesar $63.36 \%$ termasuk dalam klasifikasi baik, hasil validasi dari ahli media adalah sebesar $84.6 \%$ termasuk dalam klasifikasi sangat baik, penilaian dari guru Mata Pelajaran adalah sebesar $90.4 \%$ termasuk dalam klasifikasi sangat baik dan respon penilaian siswa didapat hasil sebesar $77.05 \%$ termasuk dalam klasifikasi sangat setuju. Nilai tertinggi didapatkan dari hasil penilaian guru Mata Pelajaran dikarenakan materi yang disajikan dengan media pembelajaran berbasis video ini sudah dapat membantu proses pembelajaran efektif. Sedangkan nilai terendah didapatkan dari hasil validasi ahli materi dikarenakan ada rumus yang belum dicantumkan pada display video pembelajaran. Data yang telah diperoleh dari ahli materi, ahli media, guru Mata Pelajaran dan siswa menunjukan bahwa media pembelajaran berbasis video masuk dalam klasifikasi layak atau dapat digunakan untuk proses pembelajaran khususnya pada mata pelajaran kerja mesin materi pembubutan ulir metris.

\section{SIMPULAN}

Berdasarkan hasil penelitian dan pembahasan maka dapat diambil kesimpulan sebagai berikut. (1) Bentuk produk media pembelajaran pada matapelajaran kerja mesin teori pemesinan bubut adalah media pembelajaran berbasis video dengan materi pembuatan ulir metris. File media pembelajaran berbasis video pada mata pelajaran kerja mesin teori pemesinan bubut sebesar 291 MB dengan format .mp4 dan dilengkapi dengan backsound, animasi serta narator. (2) Kelayakan media pembelajaran berbasis video didapat persentase rata-rata sebesar $78.85 \%$ yang termasuk dalam kategori sangat baik. Dengan demikian media pembelajaran berbasis video pada pembelajaran praktik pemesinan bubut dinyatakan layak digunakan untuk proses pembelajaran.

\section{DAFTAR RUJUKAN}

Azhar Arsyad. (2016). Media Pembelajaran. Jakarta: PT. Raja Grafindo Persada.

Azhar Arsyad. (2004). Media Pembelajaran. Jakarta: PT. Raja Grafindo Persada.

Cepi Riyana. (2007). Pedoman Pengembangan

Media Video. Bandung:Program P3AI

Universitas Pendidikan Indonesia.

Fajar U dan Febrianto A. (2017). Pengembangan Video Tutorial Untuk Pembelajaran Gambar Manufaktur SMK Kelas XI. Jurnal Pendidikan Vokasional Teknik Mesin, 5(1), 41-46.

Imam M, dkk. (2007). Pengembangan Media Pembelajaran Interaktif Berbasis Multimedia Pada Mata Kuliah Dasar Listrik. Jurnal Pendidikan Teknologi dan Kejuruan, 16(1), 1-18.

Rudi Susilana dan Cepi Riyana. (2007). Media

Pembelajaran. Bandung: CV Wacana Prima.

Smaldino, dkk. (2008). Instructional Technology and Media for Learning (Ninth Edition). NJ: Pearson Education Inc..

Sugiyono. (2011). Metode Penelitian Administrasi. Bandung: Alfabeta. 
Sugiyono. (2016). Metode Penelitian

Kuantitatif, Kualitatif, Dan $R \& D$. Bandung: Alfabeta.

Suharsimi Arikunto. (1993). Dasar-Dasar Evaluasi Pendidikan. Jakarta: Bumi Aksara.
Wawan S. (2015). Pengaruh Penggunaan Video Pembelajaran Terhadap Prestasi Praktik Pemesinan di SMK Muhammadiyah Prambanan. Jurnal Pendidikan Vokasional Teknik Mesin, 3 (7), 511-518. 